\title{
THE TRANSNATIONAL IMAGINED COMMUNITY OF THE BLACK PRESS OF SAO PAUlO AND CHICAGO, 1900-1940s
}

A comunidade transnacional imaginada da imprensa negra de São Paulo e Chicago, 1900-1940

La comunidad transnacional imaginada de la prensa negra de Sao Paulo y Chicago, 1900-1940

CRISTIÁN CASTRO

http://dx.doi.org/10.1590/S2178-14942017000100005

Cristián Castro é licenciado em História pela Universidade do Chile, M.A. e Ph.D. pela Universidade da Califórnia em Davis (Estados Unidos) e docente da Universidade Diego Portales (Chile) (cristian.castrog@mail.udp.cl).

Artigo recebido em 15 de dezembro de 2016 e aprovado para publicação em 2 de fevereiro de 2017. 


\title{
CRISTIÁN CASTRO
}

\begin{abstract}
This article explores the use of the concept of a transnational imagined community as a theoretical tool for the study of the black press of São Paulo and Chicago from 1900 to 1950. In doing so, I aim to connect the local with the global; associating the uniqueness of the historical trajectories of these specific Afro-descendant communities, to the commonalities of the struggles endured by members of the black Diaspora in the Americas. The paper's macro-narrative is informed by the story of capitalism's structural changes in the late 19th and early 20th century. These transformations provided the necessary socio-political conditions for the development of the black press; a press that aimed to articulate a counter-hegemonic discourse on race, different from the mainstream press, the 'white men's press'. At a micro-level this paper proposes the use of the black press in the Amercas as a door to understand how a fraction of the afro-descendant community in São Paulo and Chicago - namely the black middle class - negotiated race and citizenship through a complex process of national and transnational dialogue, both locally and globlly. Overall, despite the limitation of 'the black press' as a primary source due to its limited circulation and audience, the black press offers a unique opportunity to depict afro-descendants everyday urban life in two rapidly modernizing cities.
\end{abstract}

KEYwORDs: black middle class, black press, Transnational History, Global History, Urban History, black modernity.

\section{Resumo}

Este artigo explora o uso do conceito de uma comunidade imaginária transnacional como ferramenta teórica para o estudo da imprensa negra de São Paulo e Chicago de 1900 a 1950. Ao fazê-lo, busco conectar o local com o global, associando a singularidade das trajetórias históricas dessas comunidades afrodescendentes específicas aos pontos em comum das lutas sofridas pelos membros da diáspora negra nas Américas. A macronarrativa do artigo é informada pela história das mudanças estruturais do capitalismo no final do século XIX e início do século XX. Essas transformações proporcionaram as condições sociopolíticas necessárias para o desenvolvimento da imprensa negra; uma imprensa que visava articular um discurso contra-hegemônico sobre a raça, diferente da imprensa tradicional, a "imprensa dos homens brancos". Em um nível micro, este artigo propõe o uso da imprensa negra nas Américas como uma porta para entender como uma fração da comunidade afrodescendente de São Paulo e Chicago - ou seja, a classe média negra - negociou raça e cidadania através de um complexo processo de diálogo nacional e transnacional, local e globalmente. Em geral, apesar da limitação da "imprensa negra" como fonte primária, devido à sua limitada circulação e audiência, a imprensa negra oferece uma oportunidade única para retratar a vida urbana cotidiana dos afrodescendentes em duas cidades em rápida modernização.

Palavras-CHave: classe média negra, imprensa negra, História Transnacional, História Global, História Urbana, modernidade negra.

\section{RESUMEN}

Este artículo explora el uso del concepto de comunidad transnacional imaginada como herramienta teórica para el estudio de la prensa negra de São Paulo y Chicago de 1900 a 1950. Al hacerlo, intento conectar lo local con lo global, asociando la singularidad de las trayectorias históricas de estas comunidades afrodescendientes específicas a los puntos en común de las luchas que sufrieron los miembros de la diáspora negra en las Américas. La macro-narrativa del documento es informada por la historia de los cambios estructurales del capitalismo a finales del siglo XIX y principios del XX. Estas transformaciones proporcionaron las condiciones sociopolíticas necesarias para el desarrollo de la prensa negra, una prensa que pretendía articular un discurso contra-hegemónico sobre la raza, distinto de la prensa corriente, la "prensa de los hombres blancos". A nivel micro este trabajo propone el uso de la prensa negra en las Américas como una puerta para entender cómo una fracción de la comunidad afrodescendiente de São Paulo y Chicago - es decir, la clase media negra - negoció la raza y la ciudadanía a través de un complejo proceso de diálogo nacional y transnacional, tanto local como globalmente. En general, a pesar de la limitación de la "prensa negra" como fuente primaria debido a su limitada circulación y audiencia, la prensa negra ofrece una oportunidad única de representar la vida urbana cotidiana de los afrodescendientes en dos ciudades de rápida modernización.

Palabras clave: clase media negra, prensa negra, Historia Transnacional, Historia Global, Historia Urbana, modernidad negra. 
If it is wrong for a white newspaper to make white people hate colored people, how can it be right for a Negro newspaper to make colored people hate white people? Chicago COMmission on RaCe Relations (1922: 556)

The newspaper, like the modern city, is not wholly a rational product. No one sought to make it just what it is. In spite of all the efforts of individual men and generations of men to control it and make it something after their own heart, it has continued to grow and change in its own incalculable ways. ROBERT E. PARK (1925: 80)

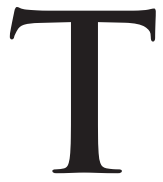

his article explores the use of the concept of a transnational imagined community, as a theoretical tool for the study of the black press of São Paulo and Chicago from 1900 to $1950 .{ }^{1}$ In doing so, I aim to connect the local with the global; associating the uniqueness of the historical trajectories of these specific Afro-descendant communities, to the commonalities of the struggles endured by members of the black diaspora in the Americas. ${ }^{2}$

This article's macro-narrative is informed by the story of capitalism's structural changes in the late nineteenth and early twentieth century. These transformations provided the necessary socio political conditions for the development of the black press; a press that aimed to forge a counter-hegemonic discourse on race, different from the mainstream press, the 'white men's press'. ${ }^{3}$

At a micro-level my research proposes the use of the black press in the Americas as a gateway to understanding how a fraction of the Afro-descendant communities in São Paulo and Chicago - namely the black middle class - negotiated race and citizenship through a complex process of national and transnational dialogue, both locally and globally. Overall, despite the limitation of 'the black press' as a primary source due to its limited circulation and audience, it offers a unique opportunity to depict Afro-descendants' everyday urban life in two rapidly modernizing cities. 


\section{THE BLACK PRESS AS A TRANSNATIONAL IMAGINED COMMUNITY}

Chapter $X$ of The Negro in Chicago: A Study of Race Relations and Race Riot, a sociological study of the race riot in that city in July 1919, opens with a quote from the historian Edmund Burke, acknowledging the importance of the press as cultural artifact in the construction of the public opinion concerning race relations:

We cannot escape the conclusion that the press is the most powerful institution in this country. It can make men; it can destroy men. It can conduct crusades; it can put an end to crusades. It can create propaganda; it can stifle propaganda. It can subvert the Government; it can practically uphold the Government. More than all this, despite theoretical laws which restrain abuses of the Press, so determined are the American people that its freedom shall not be abridged that they have written into the Constitution of the United States (Amendment I) the express provision the "Congress shall make no law... abridging the freedom ...of the press", and in practice the Press is free to destroy men, institutions and races, or to make them live, the power being limited only by the conscience and sagacity of the men who compose this powerful Fourth Estate (Chicago Commission on Race Relations, 1922: 520).

In order to understand the theoretical construction of a black transnational imagined community, this article will focus primarily, but not exclusively, on several newspapers published in the cities of São Paulo and Chicago by representatives of the black middle class. These include O Clarim da Alvorada, O Menelick, Progresso, A Voz da Raça, O Bandeirante and Brasil Novo, amongst others in the case of Brazil, and the Chicago Defender in the case of Chicago. ${ }^{4}$ These newspapers provided a public voice for blacks in two of most dynamic urban centers of the era: in the case of Brazil, the capital of the region then riding the crest of the coffee boom and undergoing rapid growth and modernization, and in the case of Chicago, the center of the industrialization process in the Midwest of the United States. These papers offer us a unique perspective on the process of the construction of an emerging black middle class and the negotiation of race and citizenship of Afro-descendants in these two distant cultural milieus.

Benedict Anderson defined a nation as an imagined political community that is imagined as both inherently limited and sovereign (Klaren, Chasteen, 2003; Doyle, Pamplona, 2006: 248-271). First published in 1983, Anderson's Imagined Communities. Reflections on the Origin and Spread of Nationalism, examines the creation and global spread of the 'imagined communities' of nationality, exploring among other historical processes, the interaction between capitalism and print. Anderson argues (1983: 7) that an imagined community is different from an actual community because it is not, and cannot be, based on everyday face-to-face interaction between its members. Instead, members hold in their minds a mental 
image of their affinity. As Anderson puts it, a nation is imagined because the members of even the smallest nation will never know most of their fellow-members, meet them, or even hear of them, yet in the minds of each member lives the image of their communion. The press creates imagined communities by targeting specific audiences or generalizing and addressing citizens as their captive audience. ${ }^{5}$ Thus, the creation of imagined communities only became possible due to the emergence of 'print-capitalism'. ${ }^{6}$

My main objective is to trace how the periodicals published by these members of the black middle classes served as cultural media that helped in the construction of a counterhegemonic racial discourse intended to fight against racism, and as a cultural artifact for their inclusion in their respective nations. This analysis will help us illustrate how the AfroPaulista and Chicagoan African-American elites used the press as a means to fulfill specific objectives: to construct a sense of community among the masses of former slaves arriving to the city in search of a non-slavery related job; to educate them in the ways of the 'civilized world' of the city in order to respond to the standards of the ideal black citizen; and finally, to protest against the racial discrimination that had persisted beyond the abolition of slavery in both cases. As Walter Benjamin argued (2008: 359) in his analysis of the newspaper as a cultural artifact: "The fact that nothing binds the reader more tightly to his paper than this all-consuming impatience, his longing for daily nourishment, has long been exploited by publishers, who are constantly inaugurating new columns to address the reader's questions, opinions, and protests." The following pages will demonstrate that the emerging black middle class of the Americas, namely, the emerging black middle class of Chicago and Sao Paulo, realized the potential power of the press and tried to use its power for their own benefit.

\section{The black press of SaO PaUlo and Chicago, 1900-1950}

$\mathrm{T}$ he first step to overcome the destructive and lingering consequences of slavery in the mind of the black men was to transform former slaves into historical subjects capable of articulating individual and collective historical consciousness. Although, according to his detractors, Karl Marx never 'saw' race as part of the equation, his definition of class consciousness and its relationship to the transformation of social relations and modes of production serves as a model for understanding the complex relations between economic structures and superstructural forms of thought:

In the social production of their existence, men inevitably enter into definite relations, which are independent of their will, namely relations of production appropriate to a given stage in the development of their material forces of production. The totality of these relations of production 
constitutes the economic structure of society, the real foundation, on which arises a legal and political superstructure, and to which correspond definite forms of consciousness. The mode of production of material life conditions the general process of social, political, and intellectual life (Marx, 1904: 11).

The emerging black middle-class of both cities accepted the task of assisting that struggle, and led the way by using the press as a means to construct an imagined community among the black population of Chicago and São Paulo; and in doing so, helped with the ontological vicissitudes of 'being' in the city (Mignolo, 2008: 229). The editors of the black press of Sao Paulo and Chicago attempted to draw the contours of a new vision of citizenship in both nations, through the construction of public discourse in which "modernity for all its amorphousness became the guiding ethos of such a vision..." (Lee, 1999: 46). The black press of both milieus reflected on racial relations by continuously imagining a community that may have had different futures or perspectives, but shared some of the subjectivities of the black diaspora in general.

\section{ORIGINS OF THE BLACK PRESS IN CHICAGO}

I

$\mathrm{n}$ the case of United States, the Chicago Defender forms part of larger tradition of black journalism that started with the era of the antebellum-antislavery movement, between 1827 and 1861, when these newspapers advocated for the freedom of slaves. Later, during the Reconstruction era, the black press shifted to an educational mode, an attempted to gain recognitions for black national identity. The fight against lynching and violence towards blacks marked the third period, from 1877 to 1915 . The Chicago Defender was probably the most important actor in the period from 1915 to the end of the WW2.

During this period the African-American press fought for equal treatment of the southern newcomers, black soldiers who had defended the nation in the wars, and pushed to improve housing and living conditions for blacks across the United States.

The birth of the Chicago Defender in 1905 inaugurated a new form of editing black newspapers in the United States. Denunciations of racial discrimination and violence were no longer the sole objective, the black press was now also a business, and contrary to the case of the black press of São Paulo, selling newspapers was crucial to keep the endeavor going. In 1920 the Defender's circulation, in terms of national subscribers, had reached 283,571.

Founded by Robert Abbott in 1905 on capital of twenty-five cents, the "World's Greatest Weekly" had grown into the largest selling black newspaper in the United States by World War I, with two thirds of its circulation outside Chicago (Grossman, 1985: 85). 


\section{Z5J,GOO PEOPLE READ CHICAGO'S ONLY WEEKIY PAPL. The Chicago Defender.}

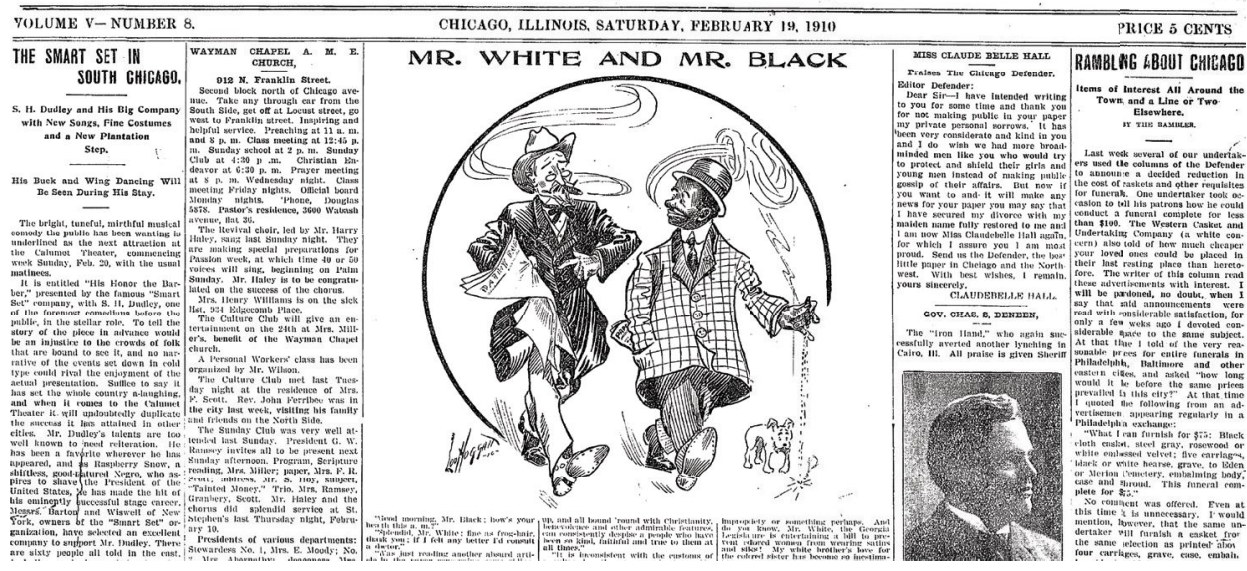

L.N. Hoggatt, "MR. WHITE AND MR. BLACK." Chicago Defender 19 Feb. 1910: 1, col. 3.

Newspapers like the Chicago Defender encouraged the migration of thousands of blacks from the south to Chicago. Furthermore, "The Defender even made arrangements with some rail companies for special-fare travel for anyone wishing it" (Grossman, 1985: 85).

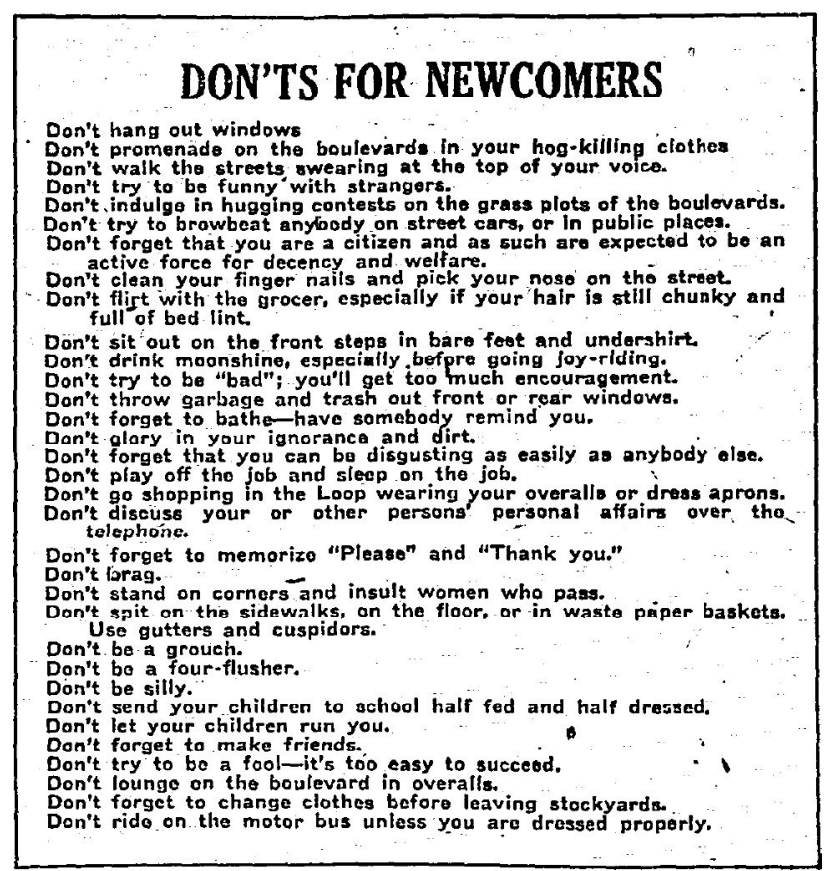

The Chicago Defender, July 14, 1923. 
The Chicago Defender published lists of 'do's and don'ts' for black behavior: do not use vile language in public spaces; do not live in unsanitary houses, or sleep in rooms without proper ventilation; do not violate city ordinances, relative to health conditions, amongst others. Here, both black presses seemed to have had the same objective. Both sought to educate the masses of former slaves that arrived in these cities of hope.

Forty-Five Thousand of the 60,000 Afro-Americans in Chicago reside on the South Side, and most of these are in the district bordered on the north by Twenty-sixth street, on the west by Federal street. Along State Street can be found nearly every line of business conducted and conducted successfully by race people. That is why, perhaps, Chicago has the reputation of offering the largest opportunity of any city in the North. And unfortunately that reputation works more harm than good to the older residents. For each year from South comes hundreds who have heard of this haven, who, instead of going slow and learning the Northern ways, sail right in where angels fear to tread, and undo all the good that has been done. As we recited in a previous article, mistaking privileges for rights. The result of which is self-evident. Perhaps through no better means could this be brought home to the newcomers than through the churches. Our pastors knowing the conditions as they exist in this city should impress it upon their congregations that they cannot lead a too exemplary life, for unfortunately we are all judged by the actions of the few. ${ }^{?}$

The main objective of the black press in the Americas was to make visible a portion of the population that was invisible to power. Blacks did not exist in the other newspapers, they were neither born, nor got married, they did not die, did not fight in any wars, never

THE AWAKENING

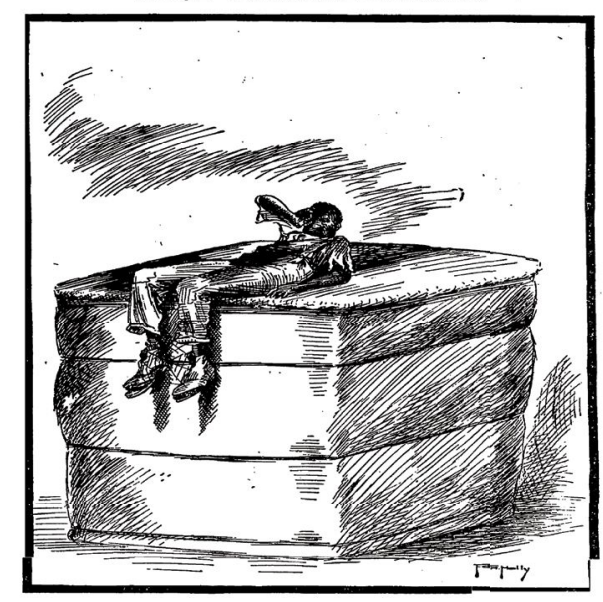

Chicago Defender(Aug 19, 1916) p.12, col. 3. 
participated in any scientific or academic achievements, they were truly invisible; unless they committed a crime. ${ }^{8}$

On the other hand, the black press showed their babies being born, showed their neighbors, showed their graduations, celebrations, showed their PhD's. The black press never pretended to be objective because they never saw the mainstream newspapers being objective. It often took a position, it had an attitude. It was a press of advocacy, there was news, but this news had an admitted, an open slant.

For over 150 years African-American newspapers were one of the strongest institutions in black America, they helped to create and stabilize communities, they spoke forcefully to the economic interest of their readers and employed thousands.

During World War I, "thousands of African Americans abandoned their southern homes and streamed into the northern industrial centers. Previously unimaginable opportunities for employment arose when the war simultaneously shut off immigration and stimulated the demand for industrial products." To many, the North represented a promise of a brighter future, and "the exodus rivaled emancipation as a liberating experience." The Chicago Defender became the "self-designated publicist and booster of the exodus" (Grossman, 1985: 85).

The Chicago Defender did not only use the words 'Negro' or 'black' in its pages, but also referred to African-Americans as 'the Race' and black men and women as 'Race men and Race women.' Its local circulation soon surpassed that of the three rival papers existing in the Chicago area at that time: the Broad Ax, the Illinois Idea, and the Conservator. The newspaper was read extensively in the South. Black Pullman porters and entertainers were used to distribute the paper across the Mason/Dixon line. The paper was smuggled into the south because white distributors refused to circulate the Defender and many groups such as the Klu Klux Klan tried to confiscate it or threatened its readers. It was passed from person to person, and read aloud in barbershops and churches. It is estimated that at its height each paper sold was read by four to five African Americans, putting its readership at over 500,000 people each week. The Chicago Defender was the first black newspaper to have a circulation over 100,000, the first to have a health column, and the first to have a full page of comic strips.

During World War I the Chicago Defender waged its most aggressive (and successful) campaign in support of 'The Great Migration' movement. This movement resulted in over one and a half million southern blacks migrating to the North between 1915-1925. The Defender spoke of the hazards of remaining in the overtly segregated south and lauded life in the North. Job listings and train schedules were posted to facilitate the relocation. It also used editorials, cartoons, and articles with blazing headlines to attract attention to the movement, and even 
went so far as to declare May 15, 1917 the date of the 'Great Northern Drive.' The Defender's support of the movement, caused southern readers to migrate to the North in record numbers.

In August 1916, the Chicago Defender published an editorial cartoon alluding to the importance of Chicago. Like the rest of the North, Chicago offered freedom from legally sanctioned racial discrimination, but industrial employers turned away African Americans who approached the factory gates. Widespread beliefs about the aptitudes of racial and ethnic groups on the part of employers relegated East and South European immigrants to the least skilled jobs in industry, while African Americans had even fewer opportunities. Allegedly incapable of regular, disciplined work, they were virtually excluded except as temporary strikebreakers, notably in the meatpacking industry in 1904.

When World War I halted immigration from Europe while stimulating orders for Chicago's manufactured goods, employers needed a new source of labor for jobs assumed to be 'men's work.' Factories opened the doors to black workers, providing opportunities for black southerners eager to stake their claims to full citizenship through their role in the industrial economy. For black women, the doors opened only slightly and temporarily, but even domestic work in Chicago offered higher wages and more personal autonomy than in the South. Information about these differences and about 'the exodus' spread quickly through the South, partly because of the Chicago Defender newspaper, which was so influential that many black southerners going to other northern cities

\section{OE NERBROES MUUROERED WEEKLY IN UNITED STATES BY WHITE AMERIGANS.}

\author{
Race Clash at Marion, Ark-Every \\ Black Is Threatened. \\ Mob Locks Up Two Negroes Pending \\ Confession. After Dragging \\ Them by Necks Through \\ Streefs. \\ R.ducation Instead of Segregntion Is \\ Needed for Both Blacks and
} Whites in the South.

West Marion, Ark., March 18,The atening rengeaws spon eveiry col ared person in Marion, Ark., five nalles east of here. 200 armed ben have locked in jail two rolored men. alleged jasl breakers, whom they have declared they will tynch at daylight. Oth. er colorel citikens in the town were attacked by the mob to-vight. Wire comamuntestion whth Mlarion is eut off.

A Iyuching was stayevi to-night for the purpose of securing a confcssion from the anen broualut here from Mem. this, Tenn., early to algtht, accordins In the declaration of the anoh leadera. The jail delivery took place Monday night, twelve urisoners escaplag, and it is helleved $n$ number of colored peoule living in Marion alted in the es. cane. One of the colored prisoners who escaped was the agsassin of a lead. ing resident.

On the arrival of the colored persons. Charles Richarilson anil Bob Austla. an ex-convict, the two tlepaty sheriffs In charge were overpowered. Bherif Lewis (white) pleaded with the moly in vain. Rojes were thrown alout the men's neck and they were dragged through the streets of the town.

Shortly before midnight the white mob locked its prisoners in the Marion jall, leaving a heavy guard in charge. A number of colored persons on the streets were beaten and threatened.

The sheriff was sent home and not a deputy sheriff has been found. The town is in the hands of the nob.

Chicago Defender, Mar 19, 1910. 
went there with images of Chicago. Equally important were the correspondence and visits that established 'migration chains,' linking Chicago with numerous southern communities, especially in Mississippi.

At least 110,000 traveled to Chicago alone between 1916-1918, nearly tripling the city's black population. The Chicago Defenderwas clearly aware that the best way to construct the idea of modern black men and women was to relate the African-American experience to the rest of the world, in so doing, the imagined community of the Defender was inevitable transnational.

\section{SaO PaUlo}

$\mathrm{W}$

hen the word of the Lei Aurea, the 'Golden Law,' or abolitionary decree, spread in the rural areas of the south-eastern region of Brazil in May 1888, the roads surrounding plantations were soon occupied by hundreds of ex-slaves ready to seek their own destiny. ${ }^{9}$ For three nights and three days the drums could be heard from all over the Paraiba Valley. Shoes, hats, suits, umbrellas or any other article of clothing that represented freedmen could be bought near the taverns. Finally freedom was a reality. But this immediate feeling of happiness triggered by emancipation was soon replaced by the necessity for a place to work. The new freedmen wondered in groups along the roads, with no clear destination. The contemporary novelist Coelho Netto, addressed the helplessness of the ex-slaves: "The Negroes were dying of hunger along the roads, they had no shelter to turn to, no one wanted them..." (Stein, 1958: 260). Slavery had been abolished but, as we will see, the former slaves' struggle was far from ending.

In Brazil the end of slavery was accompanied by a major change in the form of government, the fate of slavery was tied to the monarchy. Indeed, one year after the Lei Aurea was passed the Republic was founded. Slavery had been the backbone of the Empire's (Portuguese and Brazilian) socio-economic structure for more than three hundred years, but now it was not only unpopular among the modernizing elite of the prosperous southeast, but also within the northeastern sugar planters that were experiencing a gradual transition to sharecropping.

The end of slavery in 1888 was central for the Republic's new social context, but the Lei Aurea was the outcome of long process of social transformations. These changes had begun in the second half of the nineteenth century. During this time, the most important actor in the opposition to the monarchy was the Partido Republicano Paulista (Sao Paulo Republican Party). The PRP had been empowered by the economic shift of the center of Brazilian coffee 
production from Rio de Janeiro to Sao Paulo. Along with this relocation of economic power came a re-distribution of political power. Members of the Paulista Party members criticized three basic aspects of the monarchy's sociocultural milieu: the privileged classes and their lack of social consciousness; the persistence of slavery; and the union of church and state. In 1889, the newly founded Republic based its platform on a liberal discourse that, on the one hand, emphasized the need to correct social and political inequalities, and on the other, shed light on a fundamental paradox: at the same time that freedom for slaves was achieved, Brazilian elites were "adopting models of social analysis that viewed races as ontologically different and essentially unequal" (Schwarcz, 1993: 9).

Since 1870, the Brazilian government had implemented immigration policies that would allow the arrival of thousands of Europeans. During this period, the world had witnessed the Second Industrial Revolution and the propagation of doctrines of racial superiority. These two historical phenomena were closely linked in the case of Brazil, and would play a key role in the formation of the historical context of the final decades of the Empire and throughout the Republican period. Social Darwinism, Lamarckian eugenics, and August Comte's positivism, may have arrived late in Brazil, but they had a profound influence among the white elite. Their influences can be seen all over Brazil. From adoption of the modern flag of Brazil in November $18^{\text {th }} 1889$ with the phrase Ordem e Progesso (Order and Progress), to the construction of the Brazilian theory of whitening. Indeed, the very basis of the European Immigration policy was twofold. First, the newcomers would serve as a replacement for the labor force lost with the end of the slave trade in 1850 and passing of the first abolitionist law, known as the 1871 Lei do Ventre Livre (the Free Womb Law). And secondly, that Europeans would help Brazil in the process of whitening the population.

In the last decade of the nineteenth century the discourse of progress had managed to permeate journalists. On the day following emancipation, Sao Paulo's mainstream newspaper, Diário Popular (Popular Newspaper) described the event as:

a great good, not because of how it will benefit the black race, which, because of its backwardness, will continue to suffer almost as much as before. ... Rather, the beneficiaries will be those appropriately educated and prepared to deal with the challenges posed by the new order of things. The right man in the right place, as the Americans say (Andrews, 1991: 59).

The mixture between the ideal of backwardness that emerged from the ideal of progress and the concept of the 'survival of the fittest,' in this case, 'the right man in the right place,' help us understand the complexity of the cultural milieu that the Republic offered. 
As we have seen, the modernizing Paulista elite came to power through the use of a liberal discourse centered on the need to correct social inequalities, but in this case, abolition brought another problem to the table. The Brazilian historian Lilia Moritz addressed the paradox of the Republic:

It was as if it was possible to beckon the slaves to freedom with one hand and, armed with scientific justification, to halt them from progress with the other. In fact, the hybridization of the races in the context of such thinking meant 'chaos' (Schwarcz, 1993: 10).

Thus from its very beginning, the Republic was conditioned to restrict the equality it had offered in its political platform. European ideology thus worked as legitimating tool for the racial status quo of the post-abolition period. Afro-Brazilians found themselves free from slavery, legally equal to whites in theory, but racially discriminated in practice. (Brito, 2014) Henrique Cunha moved to Sao Paulo with his family from interior town of Pindamonhangaba around 1904. His story tells us more about how the discrimination of Afro-Brazilians operated in everyday life:

My father and my uncle were from the interior. They came to Sao Paulo because they had had problems: my father, with the priest, and my uncle, with the police. Once they went to a circus and there was a clown who made jokes; when the bear came onstage, there was a whole degrading comedy. All of the scenes made fun of blacks. And the clown sang:

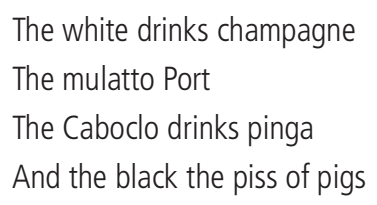

Well, they tried to burn down the circus... (Butler, 1989)

Although there is no systematic study of black migration to Sao Paulo between 1888 and 1940, the story of Henrique's father is applicable to thousands of rural risk takers who moved their entire families in search of a job. Sao Paulo, like Chicago in the United States, offered the promise of work in the industrial sector. Information obtained through interviews suggest that this migration occurred in phases.

First, we have to recognize that the black press in Sao Paulo was, as political scientist Michael Mitchell has stated, an 'opinion elite.' To try to extrapolate their stand in Brazilian society to a larger part of Afro-Brazilians would be a mistake. Paulista black newspapers were not commercial endeavors run by professional journalists and publishers but partnerships and collectives of young working men - and some women - who were part of the emerging 
Afro-Brazilian middle-class. They were people who had been labeled by their own as the 'Elite,' the 'Smart set,' and 'Princesses' (Butler, 1994: 160). They were refined, with a clear sense of style, followed society pages, and "demonstrated little sympathy for those blacks living in squalor" (Butler, 1994: 162).

Roger Bastide, a French sociologist who lived in Brazil in the middle of the twentiethcentury and probably the first scholar to undertake any research into the Black press in Brazil, had a different opinion. He believed that press discourse was not completely isolated

Table 3. Sao Paulo's Afro-Brazilian Newspapers, 1910-1935

\begin{tabular}{|c|c|c|}
\hline Title & City & Initial Publication date \\
\hline O Bandeirante & Campinas & 1910 \\
\hline O Menelick & Sao Paulo & 1915 \\
\hline Princesa do Oeste & Sao Paulo & 1915 \\
\hline A Rua & Sao Paulo & 1916 \\
\hline OXauter & Sao Paulo & 1916 \\
\hline OAlfinete & Sao Paulo & 1918 \\
\hline A Uniao & Campinas & 1918 \\
\hline O Bandeirante & Sao Paulo & 1918 \\
\hline A Libertade & Sao Paulo & 1919 \\
\hline A Protectora & Campinas & 1919 \\
\hline A Sentinella & Sao Paulo & 1920 \\
\hline O Kosmos & Sao Paulo & 1922 \\
\hline O Getulino & Campinas & 1923 \\
\hline O Clarim do Alvorada & Sao Paulo & 1924 \\
\hline Elite & Sao Paulo & 1924 \\
\hline Auriverde & Sao Paulo & 1928 \\
\hline OPatrocinio & Piracicaba & 1928 \\
\hline Progresso & Sao Paulo & 1928 \\
\hline A Chibata & Sao Paulo & 1932 \\
\hline Brasil Novo & Sao Paulo & 1933 \\
\hline Evolucao & Sao Paulo & 1933 \\
\hline A Voz da Raca & Sao Paulo & 1933 \\
\hline Cultura/O Clarim & Sao Paulo & 1934/1935 \\
\hline Tribuna Negra & Sao Paulo & 1935 \\
\hline O Estimulo & Sao Carlos & 1935 \\
\hline
\end{tabular}

Sources: Miriam Nicolau Ferrara, A Imprensa Negra Paulista, 1915-1963 (Sao Paulo: FFLCH-USP,1986, 278); Michell Mitchell, ed., The Black Press of Brazil, 1916-1969, Firestone Library, Princeton: Princeton University, n.d., microfilm; Roger Bastide, " A Imprensa Negra do Estado do Sao Paulo," Faculdade de Filosofia, Ciencias e Letras, Boletim CSSI, Sociologia, no. 2, Estduos Afro-Brasileiros, 2da serie (1951), 50-53. 
from the common Afro-Brazilian reality, because the so called black bourgeoisie were not: "so far removed from their humble origins" (Bastide, 1946: 57). Thus, these Afro-Brazilians elite operated as an ideological vanguard within the Afro-Brazilian world, but in spite of their bourgeois position, they could still relate to the masses (Guimarães, 2003: 247-269). Consequently, the editors of the Paulista black press continuously evoked the "role of AfroBrazilians in the making of the nation". ${ }^{10}$

The Brazilian black press was similar to others created within the African Diaspora. The intellectual exercise behind the construction of this press was somehow ontologically connected. First, they were meant to unify the black population and construct a sense of racial solidarity. In this case, the objective was to guide and educate Afro-Brazilians to fight against their inferiority complex produced by the proliferation of the European racist ideologies among the masses. In order to do so, the black press had mainly two strategies: overestimating black values, stating that blacks were better than whites in everything, from athletes to musicians and movie stars; or to use the idea of ridendo castigat mores, and educate by mocking the customs of the black population (Oliveira, 2016). Second, this kind of press was an instrument of protest against both explicit and subtle racial discrimination. Third, an important aspect of the black press was its social sections. Parties, meetings, club receptions, births, weddings and funerals were proof of their social status and their honorability as a race. ${ }^{11}$ Indeed, appearing in a certain club or reception meant that that someone belonged to the 'Boa Sociedade' (decent society) of that place. Thus, Afro-Brazilians could show whites that they also deserved respect. In other words, that they were not savages.

The black press of Sao Paulo between 1915 and 1937 was mainly used as a means to denounce the racial discrimination and inequality endured by Afro-Brazilians (Carvalho, 2009). On the other hand, the Paulista black press did not engage in any migration campaign; it was not necessary. Afro-Brazilians did not have a choice - São Paulo was one of the few cities in which to look for modern jobs in Brazil. Consequently, they focused on educating new AfroBrazilian men and women. As a whole, the discourse of São Paulo's black press reflected an attempt to shape attitudes regarding the political and social status of blacks in Brazilian society. Black newspapers operated on a small scale, not only because the audience for which they were intended possessed meager resources, but also because they were perceived by whites to be instruments of unwelcome racial agitation. First, we have to recognize the limitations of this press. These newspapers were the produced by a small black elite; to try to extrapolate their stand in Brazilian society to Afro-Brazilians in general would be a mistake. Second, the vast majority of these black newspapers were not commercial endeavors run by professional journalists and publishers but partnerships and collectives of young workingmen - and some 
women - who were part of the small Afro-Brazilian bourgeoisie - with some renowned exceptions, such as José Correia Leite and his role in O Clarim and O Clarim da Alvorada. These were people who had been labeled by their own as the 'Elite,' the 'Smart set,' and 'Princesses' Thus, these Afro-Brazilians elites operated as an ideological vanguard within the Afro-Brazilian social world, but in spite of their bourgeois position, they could still relate to the masses.

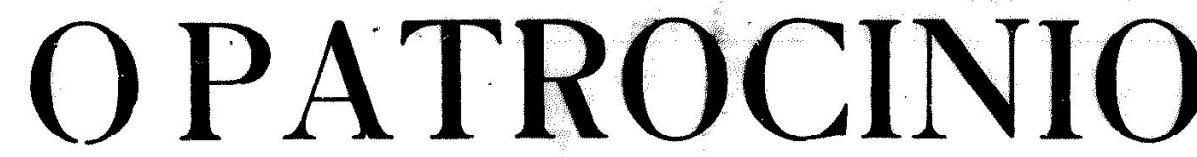

ORGAM LTERARTO, CRITICO E HUMORISTICO

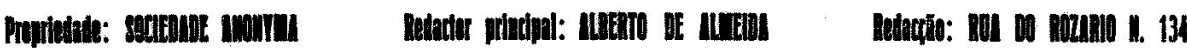

\begin{tabular}{|c|c|c|}
\hline & Aralgnolure : Rnno 54000 & \\
\hline Numero 46 & Plracicaba, 20 de Outubro de 1929 & Anno 4 \\
\hline
\end{tabular}

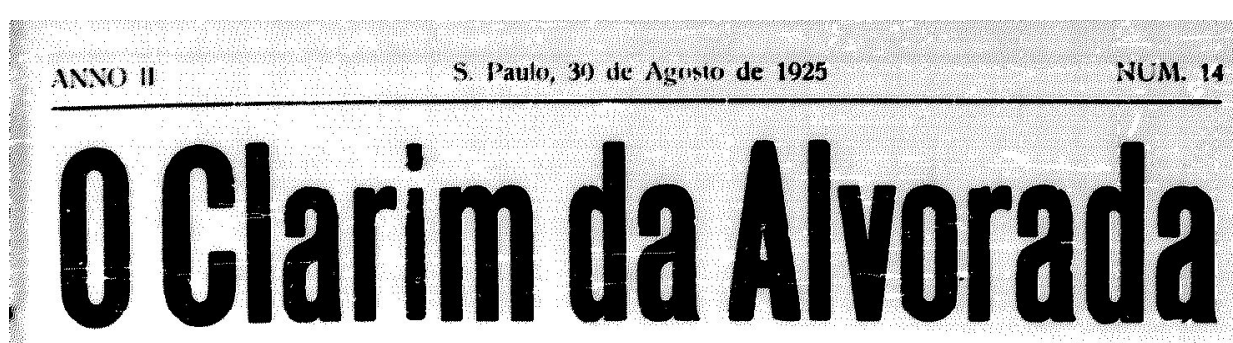

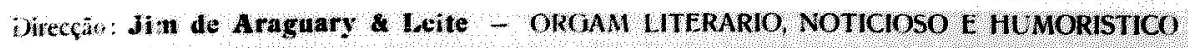
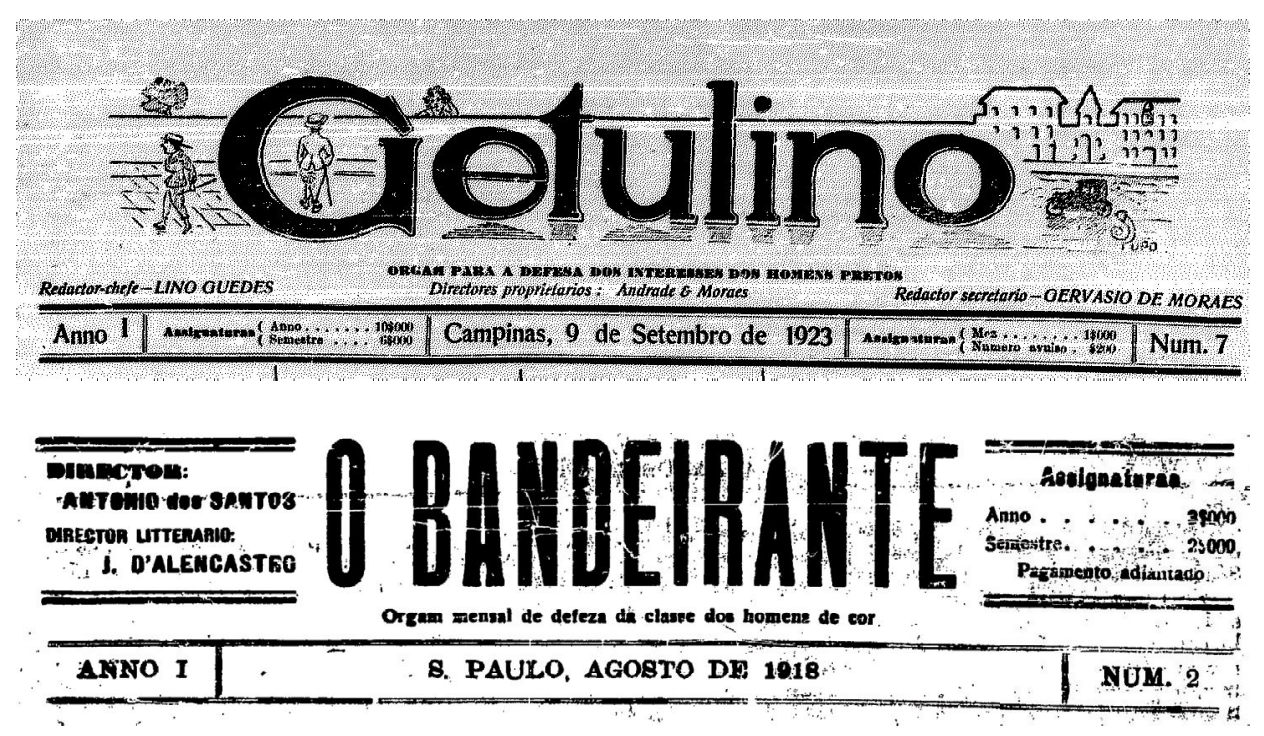


\section{CONCLUSION}

$\mathrm{T}$ he abolition of slavery in Brazil in 1888 and the end of the Civil War in the United States, in 1865 , reconfigured both socio-economical orders, remodeled social relations, and opened novel spaces of participation for 'new' social actors.

The Brazilian sociologist Florestan Fernandes argued that the condition of pauperism and social anomie of the Afro-Paulista population in the post-abolition period carried over from the days of captivity was "aggravated rather than remedied". Moreover, the black press constructed the concept of a second abolition, because the first one had been only symbolic and poor social conditions had persisted. In Chicago, the black elites' diagnosis of the former slaves was similar.

Several differences existed between the black press of Chicago and São Paulo, linked to the internal racial dynamics of both societies. Probably, the most important distinction resulted from the differences between the racial phenotype based categorization in Brazil and onedrop rule in the case of the United States. In Brazil, mulattos could have the 'choice' of not endorsing blacks due to the fact that they were treated differently as their skin was lighter. In the United States, the one-drop rule 'forced' solidarity, and as a consequence of this the market for the black press was larger.

The Chicago Defender and the black press of Sao Paulo aimed to narrate the everyday experience of their communities: racial prejudices, discrimination, abuses. As a whole, the black press had the objective of communicating their world view, their morals, and ways of being. It was used as a form of resistance. For the editors of the black press, the 'white press,' or mainstream press, did not think of them as historical subjects. For the white press blacks were invisible. They did not get married, did not die, or form organizations. The only time Afro-descendants were mentioned in the mainstream press was because of crime, vagrancy, or other judicial episodes.

In constructing a local narrative, a local set of beliefs and common ethos, the publishers of the black press needed to compare themselves to other realities endured by members of the black diaspora. The quotations that opened the black press section are prove of this. This is perhaps a crucial aspect of the black press in this period, and one of the hypotheses tested in this chapter: the black press was ontologically transnational, in constant 'dialogue' with different nations, or groups of people sharing an ethnicity, language, and culture. The black press aimed to construct a black transnational imagined community as a space to discuss their historical trajectories, to let the world know the racial prejudices that different members of the black diaspora suffered, to communicate their 
racial pride, their condition as 'decent' people, their right to be treated like respectable men and women, worthy of equal rights.

The editors of the black press needed to construct new black men. In order to do so, these elites had to start by degrading all of the stereotypes that were related to blacks: rudeness, alcoholism, laziness, crime and social anomie.

Another point of comparison among these newspapers: the symbolic role given to Africa in the message delivered by the black middle class. In Sao Paulo, the black elite had to be able to restore blacks a sense of honor. To do so, the Paulista black press constructed a contradictory discourse in which Africa had a twofold meaning. On the one hand, Africa was used as a unifying ethos, a common past that was seen as a worthy motherland, but on the other hand, Africa was also portrayed as a primitive land that had been left behind on a painful but irreversible path. The newspaper O Getulino, stated this message clearly: "Our ancestors came in ships from the land of Africa, but with that said, we declare that we have our own ship and nation, this country...We are not Africans, we are Brazilians." On the contrary, most black American middle-class people did not identify with African intellectuals.

In the minds of the Afro-Paulista elite and the editors of the black press of Chicago, one of their main objectives was to build a new black man as worthy of incorporation into the labor force like any other citizen. For these elites, the social conditions that would allow the construction of a black community were similar to E.P. Thompson's idea of the process of formation of class: "Class happens when some men, as a result of common experiences (inherited or shared), feel and articulate the identity of their interests as between themselves, and as against other men whose interests are different from theirs." Thus, the process of building an imagined community through the press implied a complex process of relating their (inherited and shared) past experience with a different and more respectful present and future. Thompson's definition of class introduces another element that should be taken into account when we think about the process of community formation. According to Thompson, identity is also constructed as an opposition to others. In the case of Chicago and São Paulo, the arrival of the black newcomers was not a peaceful process. Both cities received important waves of immigrants from Europe during the nineteenth century. Irish, German, Swedes, Jews, Polish, Italians, Japanese, Portuguese, and Greeks were part of the multiethnic composition of Chicago and São Paulo. The arrival of blacks from the south of the United States and from the interior of São Paulo and the northeast of Brazil transformed these two different milieus into urban battlefields for the negotiation of social, political and cultural identities. These different ethnic groups also managed to produce their own newspapers. Similarly, the industrial revolution and accompanying demographic revolution were the backgrounds to the greatest transformation in history, revolutionizing 'needs' and destroying 
the authority of customary expectations. This is what most separates the 'pre-industrial' or 'traditional' from the modern-world. (Thompson, 1993: 14)

The black press of Sao Paulo and Chicago reflects the emergence of a global black imagination which had similar idealized visions of what a modern and respected black community should be like. On the one hand, Afro-Brazilians' depiction of the important role played by African-Americans in the construction of American civilization, seemed to miss that at that same time racial lynching was part of everyday life in the US, and that the 'respect of the white race,' was not as clear as they imagined. On the other hand, Robert Abbott's statement that individual progress in Brazil was not linked to the color of the skin but to 'sheer ability, falls into what has been labeled as the reaffirmation of the myth of Brazilian racial democracy. Thus, despite being biased and inexact, the importance of these quotations is that they reflect black intellectuals' investments in consolidating the transnational political desires of the race, their forms of an imagined community.

\section{Notes}

1 In the case of Latin America, John Charles Chasteen synthesizes some of the changes addressed in this chapter: "Overall, Latin America's contemporary nation-state consolidated themselves only after 1850. The onset of export-driven economic growth, a regionwide trend from the 1870s onwards, helped unify national elites. Export growth produced newly robust tax revenues, providing the resources necessary for the creation of social infrastructure and state institutions, such as effective national bureaucracies, school systems that reached beyond capital cities, and disciplined armies and police forces. New technologies of weaponry (such as long-range rifles), transportation (such as railroads and steamships), and communication (such as telegraph lines that connected Latin American capitals to Europe and to their own hinterlands) strengthened modernizing central governments. Latin Americanists have tended to emphasize the importance of state consolidation as a precondition for inculcating a widely-shared vision of national identity. Many would go so far as to say that "true nationalism is a twentieth-century phenomenon in Latin America" (Castro-Klaren, Chasteen, 2003: xviii).

2 Barbara Weinstein and Rebecca Scott have compared ideas of citizenship and national identity in the postabolitionary period in the U.S. South and Latin America (Scott, 2005; Weinstein, 2006).

3 Carolyn Martindale's The White Press and Black America explores the general trends behind the analysis on the role of the press in depicting and constructing 'black America' (Martindale, 1986: 178).

4 The Defender was not the only black newspaper, we should also mention: The Appeal, The Broad Axe, The Conservator and The World. I will focus on the Defenderdue to its important role in the internal black diaspora with the United States, and the importance of this migration in the history of the black diaspora in general.

5 Leo Ou-Fan Lee (1999: 41-83) discusses the construction of modernity in print culture using Benedict Anderson's concept of the imagined community: "Benedict Anderson's widely cited book has led us to believe that a nation is first an 'imagined community' in itself based on a conception of simultaneity marked by temporal coincidence and measured by clock and calendar. The technical means for representing this imagined 
community, according to Anderson, are two forms of print culture - newspapers and novels - that first flowered in the eighteenth and nineteenth centuries in Europe."

6 Anderson arrived at his theory because he felt that neither Marxist nor liberal theory adequately explained nationalism. Anderson falls into the 'historicist' or 'modernist' school of nationalism along with Ernest Gellner and Eric Hobsbawm in that he posits that nations and nationalism are products of modernity and have been created as a means for political and economic ends. This school stands in opposition to the primordialists, who believe that nations, if not nationalism, have existed since early human history. Imagined communities can be seen as a form of social constructionism on a par with Edward Said's concept of imagined geographies. In contrast to Gellner and Hobsbawm, Anderson is not hostile to the idea of nationalism nor does he think that nationalism is obsolete in a globalizing world. Moreover, he values the utopian element in nationalism. According to his theory of imagined communities, the main causes of nationalism are the declining importance of privileged access to particular script languages because of mass vernacular literacy; the movement to abolish the ideas of rule by divine right and hereditary monarchy; and the emergence of printing press capitalism - all phenomena occurring at the start of the Industrial Revolution. (Gellner, 2009; Hobsbawm, 1990; Said, 1979).

7 Chicago Defender, Apr 18, 1914.

8 Chicago Defender, Apr 30, 1910.

9 Auriverde, May 13, 1928.

10 O Getulino, 7 September, 1924.

11 o Alfinete, September 22, 1918

\section{NeWSPAPER SOURCES}

O Alfinete, September 221918.

O Getulino, 7 September 1924.

Auriverde, May 131928.

The Chicago Defender, 19 Feb, Mar 19 and Apr 30 1910; Apr 18, 1914; Aug 19 1916; July 141923.

\section{BIBLIOGRAPHY}

AMÂNCIO, Kleber Antonio de Oliveira. Pós-abolição e quotidiano: ex-escravos, ex-libertos e seus descendentes em Campinas 1888-1926. Campinas: Alameda Casa Editorial, 2016

ANDERSON, Benedict. Imagined communities, Reflections on the origin and spread of nationalism. New York: Verso, 1983.

BASTIDE, Roger. Estudos afro-brasileiros n² 2. Sao Paulo: Universidade de São Paulo, 1946.

BENJAMIN, Walter. The work of art in the age of its technological reproducibility and other writings. Harvard: Harvard University Press, 2008.

BRITO, Luciana da Cruz. Impressóes norte-americanas sobre escravidão, abolição e relações raciais no Brasil escravista. São Paulo, 2014. Tese de doutoramento em História, FFLCH-USP. 
BUTLER, Kim. Interview with Henrique Cunha, Sao Paulo, January 20, 1989.

. Identity and self-determination in the post-abolition African Diaspora: Sao Paulo and Salvador, Brazil 1888-1938. Dissertation, Johns Hopkins University, 1994.

CARVALHO, Gilmar Luiz da. A imprensa negra paulista entre 1915 e 1937: características, mudanças e permanências. São Paulo, 2009. Tese de doutoramento em História, FFLCH-USP.

CASTRO-KLAREN, Sara; CHASTEEN, John Charles. Beyond imagined communities, Reading and writing the nation in Nineteenth-Century Latin America. Baltimore: Johns Hopkins University Press, 2003.

CHICAGO COMMISSION ON RACE RELATIONS, The negro in Chicago; a study of race relations and race riot. Chicago: University of Chicago Press, 1922.

Diario Popular (May 14, 1888), in ANDREWS, George Reid. Blacks and whites in Sao Paulo, 1888-1988. Madison: University of Wisconsin Press, 1991.

GELLNER, Ernest. Nations and nationalism. Ithaca: Cornell University Press, 2009.

GROSSMAN, James. Blowing the trumpet: The Chicago Defender and black migration During World War I. Illinois Historical Journal, Vol. 78, no. 2, summer, 1985.

GUIMARÃES, Antonio Sérgio Alfredo. Notas sobre raça, cultura e identidade na imprensa negra de São Paulo e Rio de Janeiro, 1925-1950. Afro Asia, 29/30, 2003.

HOBSBAWM, Eric. Nations and nationalism since 1780: programme, myth, reality. Cambridge: Cambridge University Press, 1990

LEE, Leo Ou-Fan. Shangai Modern: the flowering of a new urban culture in China, 1930-1945. Harvard: Harvard University Press, 1999.

MARTINDALE, Carolyn. The white press and black America. New York: Greenwood Press, 1986.

MARX, Karl. A contribution to the critique of political economy. Chicago: Charles Kerr Company, 1904.

MIGNOLO, Walter D. "The Geopolitics of Knowledge and Colonial Difference," in MORANA, Mabel; DUSSEL, Enrique; JAUREGUI, Carlos (Ed.). Coloniality at Large: Latin America and the Postcolonial Debate. Durham, Duke University Press, 2008.

PARK, Robert E.; BURGESS, ErnestW. The City. Suggestions for Investigations of Human Behavior in the Urban Environment. Chicago, University of Chicago Press, 1925.

SAID, Edward. Orientalism. New York, Vintage Books, 1979.

SCHWARCZ, Lilia Moritz. O Espectáculo Das Raças: Cientistas, Instituciones, e Questao Racial no Brasil 18701930. São Paulo, Companhia Das Letras, 1993.

SCOTT, Rebecca J., Degrees of Freedom. Louisiana and Cuba After Slavery. Cambridge, Harvard University Press, 2005.

STEIN, Stanley. Vassouras, A Brazilian Coffee County, 1850 - 1900. New Jersey, Princeton University Press, 1958. THOMPSON, Edward P. Customs in Common: Studies in Traditional Popular Culture. New York, The New York Press, 1993.

WEINSTEIN, Barbara. Slavery, Citizenship, National Identity in Brazil and U.S. South, in DOYLE, Don H.; PAMPLONA, Marco Antonio (Ed), Nationalism in the New World. Athens. University of Georgia Press, 2006. 